\title{
Inverting the Lens: White Privilege Denial in Evaluations of Politicians and Policy
}

\author{
Reagan Dobbs and Stephen P. Nicholson
}

\begin{abstract}
Public understandings of race in the United States have evolved, at least among some, to acknowledge that whiteness confers privilege. In contrast to the negative racial stereotypes that animate racial resentment, white privilege inverts the lens by focusing on whites and the notion that whiteness confers unearned advantages. Given the centrality of race in American politics, we investigate white privilege denial and whether it matters politically. Our inquiry shows white privilege denial is a distinct racial construct and that nearly half of whites are at least somewhat in denial with nearly one-third rejecting all the white privilege items. We found that white privilege denial is politically consequential, helping explain white attitudes across a range of political attitudes including support for political leaders, parties, and public policy. To capture the range and complexity of racial attitudes among whites, we recommend that studies of racial attitudes in politics include white privilege denial.
\end{abstract}

A list of permanent links to Supplemental Materials provided by the authors precedes the References section.

Reagan Dobbs (1) is a Political Science Doctoral Candidate at the University of California, Merced (rdobbs2@ucmerced. edu). Before advancing to candidacy, she served as the department's lab manager for two years. Dobbs received a B.A. in Political Science at the University of Arkansas at Monticello in 2017. Her research interests include American politics, judicial politics, and public opinion. Dobbs' dissertation, "Symbols on Parade: The Subtle Reinforcement of Government Legitimacy Attitudes," considers how judicial symbols (e.g., black robes) shape legitimacy perceptions of courts. She uses survey and experimental data to examine this relationship and determine whether it extends to other governmental institutions.

\section{Stephen P. Nicholson (1) is the Philip H. Alston}

Jr. Distinguished Professor in the Department of Political Science at the University of Georgia (snicholson@uga.edu). He received his B.A. from the University of California, Los Angeles in 1989 and his Ph.D. from the University of California, Davis in 1998. He has published numerous peerreviewed articles on political behavior, public opinion, political psychology, and direct democracy. Nicholson is co-editor of Advances in Political Psychology, a journal of the International Society of Political Psychology (ISPP) and serves on the editorial boards of Political Behavior and Journal of Experimental Political Science.

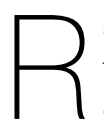
acial animus is the primary focus of research on white racial attitudes in the United States. While expressions of negative affect towards racial minorities have changed over time, understandings of race have likewise evolved to recognize what it means to be white. So even as survey measures of racial animosity remain a powerful tool for capturing white racial attitudes, scholarly (and increasingly public) understandings of race have evolved, to some extent, to recognize that whiteness confers privilege (McIntosh 1988). These advantages, which are systemic, include greater social status, material welfare, and freedom from ill-treatment (DuBois 1935; Pager and Shepard 2008; Rothstein 2017; Trounstine 2016).

Yet these advantages are hidden or not easily observed by whites because they constitute everyday "normal" life. White privilege denial is a subtle and frequently overlooked type of racial thinking, one that quietly, but powerfully, rejects the idea that there are unearned advantages of being white. White privilege is a distinctly intergroup concept, capturing the positive self-regard whites derive from their high status in the racial hierarchy. Given the centrality of race in American politics (Hutchings and Valentino 2004), we introduce a measure of white privilege denial, explore its relationship to other prominent racial constructs, and examine whether, and how, it is pertinent to whites' thinking about the political world.

Using the Cooperative Congressional Election Study (CCES), we examine the role of white privilege denial during the 2016 presidential election and two years later, during the 2018 midterm election, replicate and extend 
the analyses. Although related to other racial constructs, we found white privilege to be a distinct attitude. Nearly half of whites exhibit at least some denial of white privilege and nearly a third deny all the items in the index. In exploring its political manifestations, we found white privilege denial to be associated with evaluations of the 2016 presidential candidates and presidential approval (Obama). In the 2018 midterm election, we revisited presidential approval (Trump) and extended the analyses to a wide-ranging examination of racial(ized) policy attitudes, further demonstrating the political relevance of white privilege denial to politics.

We conclude by suggesting that white privilege denial become a central attitude of inquiry in the study of racial attitudes and politics. Although racial animus is a powerful predictor of political attitudes, especially now that racially explicit appeals have become more acceptable (Valentino, Neuner, and Vandenbroek 2018), it is limited in capturing how whites think about race. White privilege denial, a largely hidden but potent form of bias, focuses on how whites, as a privileged group, think about their advantaged position in the social order. Beyond measures of racial animus and white identity, white privilege denial provides new understandings of the powerful role that race plays in American politics.

\section{Racial Attitudes, Old and New}

White racial attitudes in the United States have changed dramatically over the last hundred years. The rationale for chattel slavery and the subsequent oppression of African Americans that followed emancipation drew on the doctrine of biological racism, the idea that Blacks are genetically inferior to whites. Many whites believed Blacks to be of lower intelligence and character and, consequently, deserving of subordinate status as an inherently "lesser" race. The decline of biological racism is widely attributed to a shift in elite discourse about race, a turn that repudiated and diminished (but did not extinguish) biological explanations (Banks 2014; Hutchings and Valentino 2004; Jardina and Piston 2019; Kinder and Sanders 1996).

After the decline of biological racism, white attitudes about race changed, taking on an egalitarian character with large majorities of whites endorsing the principle of equal treatment and integration of the races (Schuman et al. 1997). In other words, white support for legal discrimination plummeted. Although support for the principle of equal treatment was (and is) widely embraced, white respondents consistently exhibited less enthusiasm for public policy solutions addressing racial inequalities (Schuman et al. 1997). Much of the reason for this gap is that racial animosity did not end with the demise of biological racism but instead was manifested in a newer, "subtler" form of racism.
In place of biological racism emerged understandings of racial inequality rooted in societal and individual causes (Hutchings and Valentino 2004; Kinder and Sanders 1996; Kinder and Sears 1981; Myrdal 1944). Inequalities between Blacks and whites came to be understood either as a matter of white discrimination against Blacks (the racially progressive argument) or a lack of motivation shown by Blacks (the racially conservative argument). Most whites subscribed to the latter view (Schuman et al. 1997), at least initially. The perception that Blacks are not willing to apply themselves, coupled with the idea that they take what they have not earned, are the twin pillars of symbolic racism (Sears and Henry 2003) or racial resentment (Kinder and Sanders 1996; Kinder and Sears 1981). Much like biological racism, these new understandings of race stem from antipathy toward Blacks. Yet rather than proclaiming the biological inferiority of Blacks, racial resentment is presumably more subtle or implicit because it calls out Blacks for violating traditional values such as hard work and not taking more than one deserves. As made clear by Kinder and Sanders (1996), the racial resentment scale avoids referencing inborn abilities and instead fixates on questions of character, or the lack thereof.

Since racial resentment focuses on Black disadvantage it is inherently limited in what it can say about how whites think about race. From the perspective of whites, Black disadvantage minimizes (or erases) white advantage, marking racial inequality as a "them" problem. In addition, as research on intergroup relations has aptly shown, ingroup bias and outgroup prejudice are distinct concepts and there are generally weak and inconsistent relationships between them (Brewer 1979, 1999). Rather than fueling animosity towards outgroups, positive ingroup sentiment is often accompanied by indifference towards outgroups. In short, outgroup hate is not simply the reciprocal of ingroup love. Jardina (2019) advances these insights in her study of white identity (and group consciousness) and its political manifestations, showing that white identity (and group consciousness) is relevant to understanding support for politicians and public policy (also see Chudy, Piston, and Shipper 2019; Jefferson and Takahashi 2021; Schildkraut 2019), especially when they are perceived to benefit the group interests of whites.

Although white identity turns the theoretical lens inward revealing the depth and boundaries of ingroup assimilation and group solidarity, it does not emphasize group differentiation, a key aspect of intergroup relations. Since a strong motivation for identifying with a group is to provide a positive sense of self, individuals seek to not only differentiate their group from others but to do so in a way that reflects positively on the ingroup. According to Tajfel and Turner, "the aim of differentiation is to maintain or achieve superiority over an out-group on some dimensions" (1979, 41). Members of the high-status 
group seek to maintain the legitimacy of the social hierarchy by maintaining positive social comparisons. The positive distinctiveness of higher status groups, however, can be made insecure from "a conflict of values, i.e., it is conceived by some as based on unfair advantages, various other forms of injustice, exploitation, illegitimate use of force, etc." (Tajfel 1974, 79). Members of high-status groups therefore reject challenges to positive distinctiveness, especially challenges to the legitimacy of their higher status. In three words: white privilege denial.

As a challenge to the legitimacy of the racial status hierarchy, a primary source of positive distinctiveness, we look at the concept of white privilege, the largely invisible, unearned advantages associated with being white (McIntosh 1988). Although he did not coin the term, the concept of white privilege borrows from DuBois' (1935) insight about "the wage of whiteness," the psychological and social benefits the white working class received from being aligned with white elites rather than the Black working class. More tangibly, DuBois discussed how poor whites benefited from belonging to white society by having access to better schools, higher paying jobs, and extra leniency in the criminal justice system. Access to these and other resources and benefits were, and continue to be, codified through public policy creating structural inequalities (e.g., Pager and Shepard 2008; Rothstein 2017; Trounstine 2016).

Racial privilege is nearly invisible to white people (Golash-Boza 2017; McIntosh 1988; Phillips and Lowery 2018). According to Golash-Boza $(2017,187)$, "If you are White, it can be difficult to notice that you are not being followed around the store; that people are smiling at you on the street instead of clutching their purses; that no one asks you if you speak English; that you are not asked for identification when paying with a credit card." In other words, it is "normal," everyday life for most white people. While many whites acknowledge racial inequality and the disadvantages of being a person of color (Branscombe, Schmitt, and Schiffhauer 2007), some do not consider themselves to be part of a racial social order, much less residing at the top of it (Hartmann, Gerteis, and Croll 2009).

The desire to maintain a positive self-concept cloaks privilege and in the aggregate, practiced by many whites, creates a "herd invisibility" that protects the position of whites in the racial hierarchy (Phillips and Lowery 2018). Whites may be reluctant to acknowledge the advantages associated with whiteness (Conway et al. 2017), and when confronted with the idea that they have benefited from their race, deny the existence of white privilege (Knowles et al. 2014) or that it applies to them (Phillips and Lowery 2015; De Sante and Smith 2020a). In sum, white privilege denial is a subtle, but powerful, form of racial bias that maintains advantaged position of whites in the racial hierarchy and "promote[s] insensitivity and inaction with respect to racial inequality" (Knowles et al. 2014). Whereas the dominant approach to studying white racial attitudes, racial resentment, is centered on the notion that Blacks have created their own disadvantages, white privilege denial is about dismissing the advantages of whiteness to maintain positive comparisons to other racial groups.

Not only have scholars uncovered how whites understand their position in the racial hierarchy through white privilege and related concepts such as color-blindness (Bonilla-Silva 2006) but such understandings have intensified public discussions in recent years, especially in the aftermath of protests against racial injustice and police brutality arising from George Floyd's death. With the advent of social media, phrases such as "check your privilege" have drawn attention to the advantages associated with being white and have come to animate public discussions of racism and racial inequality. Regardless of whether a white person has been exposed to the concept of white privilege, we are interested in whether, and how, denying its existence manifests itself in the political world.

We proceed in two steps. In the first, we introduce our measure of white privilege denial and compare it to other prominent measures of racial attitudes including racial resentment, white identity, and white group consciousness. In the second, we examine the political relevance of white privilege denial by looking at various political manifestations including evaluations of political figures and policy attitudes.

\section{Measuring White Privilege Denial}

Our data come from the 2016 and 2018 Cooperative Congressional Election Study (CCES), a nationally descriptive internet survey of the U.S. population (see Ansolabehere and Rivers 2013). The analyses are limited to white respondents, producing 770 cases in 2016 and 762 cases in $2018 .^{1}$ For our measure of white privilege denial, we borrow three items from Swim and Miller's (1999) white privilege scale to capture the extent to which whites, at the group level, acknowledge systemic racism and the unearned advantages of Whiteness (refer to online appendix A). ${ }^{2}$ The white privilege denial scale (WPD) is, to our knowledge, novel in the study of white racial attitudes and politics (but see Chudy, Piston, and Shipper 2019 and DeSante and Smith 2020b for measures of white racial attitudes that include items on white privilege).

We also examine how WPD is related to other prominent measures of racial attitudes and, of course, include them as controls when we examine the relationship between WPD and political outcomes. For racial resentment (RR), we use Kinder and Sanders' (1996) four-item canonical measure frequently used in studies of white racial attitudes. Respondents rated their level of agreement on a 5-point scale ranging from "Strongly disagree" to "Strongly agree" on the items for each scale, depicted in table 1 , and are coded such that higher values represent 


\section{Table 1}

\section{Racial attitude items}

White Privilege Denial

- White people have certain advantages that minorities do not have in this society (reverse coded).

- I feel that White skin in the United States opens many doors for Whites during their everyday lives (reverse coded).

- I do not feel that White people have any benefits due to their race.

Racial Resentment

- Over the past few years, Blacks have gotten less than they deserve (reverse coded).

- Irish, Italians, Jewish, and many other minorities overcame prejudice and worked their way up. Blacks should do the same without any special favors.

- It's really a matter of some people not trying hard enough; if Blacks would only try harder they could be just as well off as Whites.

- Generations of slavery and discrimination have created conditions that make it difficult for Blacks to work their way out of the lower class (reverse coded).

White Identity

- How important is being White to your identity?

White Consciousness

- How likely is it that many Whites are unable to find a job because employers are hiring minorities instead?

- How important is it that Whites work together to change laws that are unfair to Whites?

\section{Figure 1}

Distributions of white privilege denial
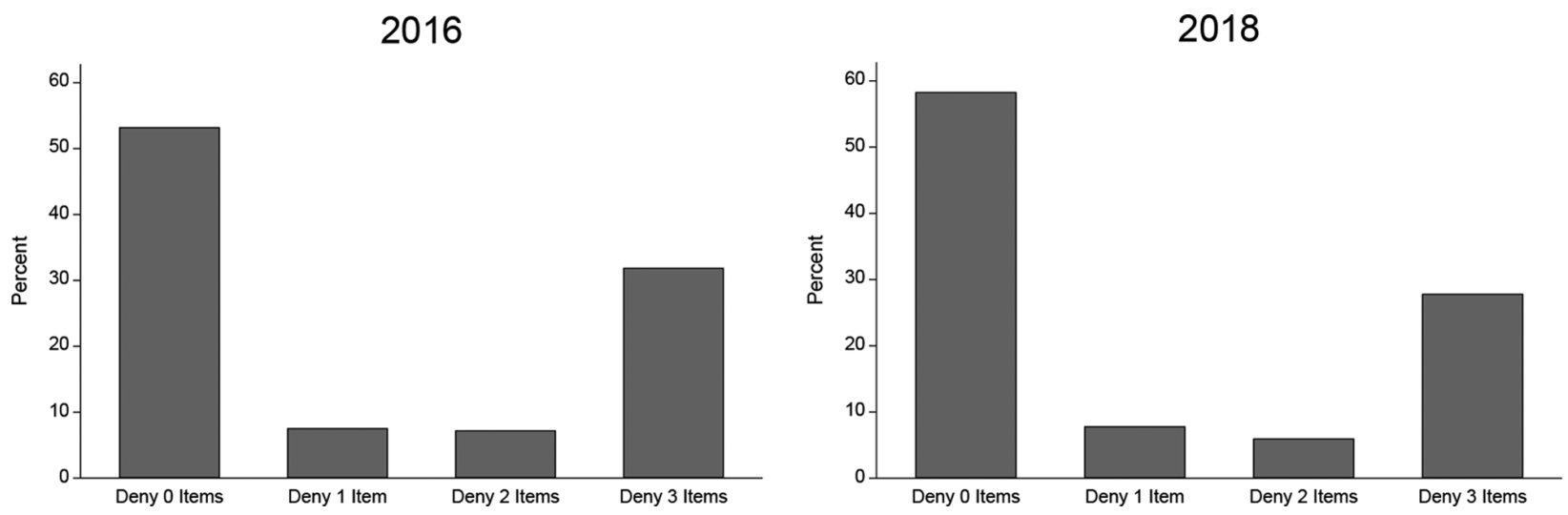

greater denial of white privilege or racial resentment. Following Jardina (2019), we also examine white identity and white consciousness, both of which are coded such that higher values represent stronger identity or higher group consciousness.

Figure 1 depicts how many white privilege items respondents denied in both years of our inquiry. In 2016, a slim majority of whites agreed with all the white privilege items (53\%), although nearly half are in denial of one or more items. Among those who acknowledged any denial, $16 \%$ are a little in denial (one item was endorsed), $16 \%$ are mostly in denial (two items were endorsed), and a little over two-thirds (68\%) exhibit strong denial (all three items were endorsed). Results are similar in 2018, in which $58 \%$ of whites deny zero items, $8 \%$ of whites deny one item, $6 \%$ of whites deny two items, and $28 \%$ of whites

deny all three items. Of the deniers, $19 \%$ were a little in denial, $14 \%$ were mostly in denial, and $67 \%$ expressed the highest denial possible on the index.

Next, we examined the relationship between WPD and other racial attitudes. As mentioned, there are generally weak and inconsistent relationships between ingroup love and outgroup hate, so WPD may only be weakly related to RR. Yet WPD is a measure of social comparison, not a measure of identity or group consciousness, so for those whites desiring to reject challenges to their group's high status we might expect a strong relationship between WPD and RR. Figure 2 compares the distribution of each racial attitude for both years of our analyses, where each of the respective scales are rescaled to range between 0 and 1 (higher values reflect greater denial or resentment). In 2016, WPD resembles a bimodal distribution with 


\section{Figure 2}

\section{Distributions of white privilege denial and racial resentment}
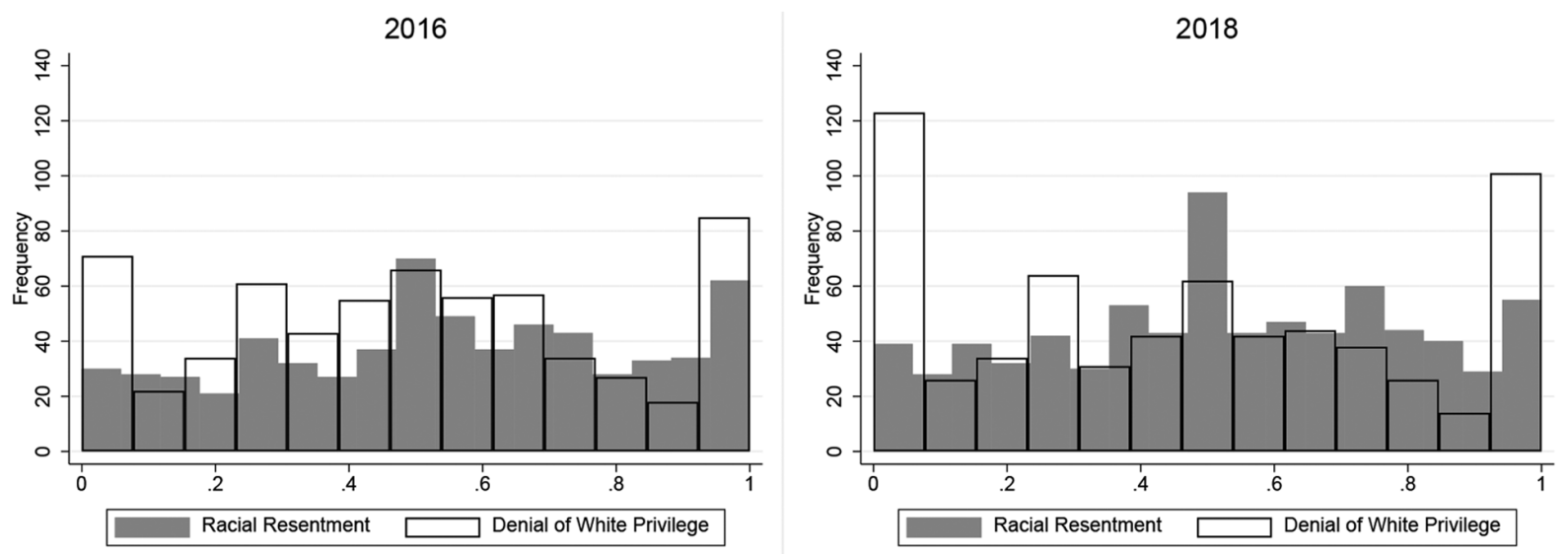

responses clustered at the extremes $(M=.498, s d=.0125)$ whereas $\mathrm{RR}$ approximates a normal distribution $(\mathrm{M}=$ .544 , sd $=.0116$ ) further suggesting they are distinct attitudes. In 2018, the bimodal distribution of WPD and the unimodal distribution of RR come into sharper focus. Nevertheless, the mean values for WPD and RR in 2018 are very similar to those in 2016. In 2018, WPD has a mean of $.464(\mathrm{sd}=.014)$ and $\mathrm{RR}$ a mean of $.525(\mathrm{sd}=$ .01 ). As is the case with RR, the distribution of WPD varies by ideology suggesting that both WPD and RR have joined the ideological or partisan divide (refer to online appendix B).

To directly address the question of whether WPD and $\mathrm{RR}$ are distinct, we conducted an exploratory factor analysis to examine whether each set of items is represented by a single factor or whether they load onto separate factors. Since WPD and RR are related constructs, we use promax rotation which assumes the measures are related. Thus, even though the constructs are corelated, we can determine whether WPD and RR can be meaningfully distinguished from one another (as well as from other related racial constructs).

The left side of table 2 displays the results of the factor analysis of the racial attitude items in 2016. WPD appears to be a meaningfully distinct construct from RR. The WPD items load strongly onto a single factor, especially the first two items that each load above.8. The third WPD item appears to be better represented on the first factor (.52) as well since it loads weakly onto the second factor (.29). Importantly, none of the RR items appear to load onto the same factor as WPD suggesting that racial resentment is distinct from white privilege denial. Although distinct, the two factors correlate at .7, suggesting they are solidly related. As a scale, the RR items also

\begin{tabular}{|c|c|c|c|c|}
\hline \multirow[b]{2}{*}{ Variable } & \multicolumn{2}{|c|}{2016} & \multicolumn{2}{|c|}{2018} \\
\hline & $\begin{array}{c}\text { Factor } \\
1\end{array}$ & $\begin{array}{c}\text { Factor } \\
2\end{array}$ & $\begin{array}{c}\text { Factor } \\
1\end{array}$ & $\begin{array}{c}\text { Factor } \\
2\end{array}$ \\
\hline WPD 1 & 0.827 & 0.0795 & 0.8855 & 0.0469 \\
\hline WPD 2 & 0.8312 & 0.0399 & 0.9194 & -0.01 \\
\hline WPD 3 & 0.5214 & 0.29 & 0.8233 & 0.0226 \\
\hline RR 1 & 0.2682 & 0.346 & 0.2533 & 0.05 \\
\hline RR 2 & 0.0536 & 0.8028 & 0.2763 & 0.575 \\
\hline RR 3 & 0.0849 & 0.8053 & 0.1971 & 0.6166 \\
\hline RR 4 & 0.3473 & 0.3351 & 0.3255 & 0.0388 \\
\hline WI & & & -0.1939 & 0.0473 \\
\hline WC 1 & & & 0.3347 & 0.2723 \\
\hline WC 2 & & & 0.14 & -0.0576 \\
\hline
\end{tabular}

exhibit less coherence. The first and fourth RR items load weakly onto two separate factors below the conventional threshold of .4. However, the second and third RR items load strongly onto factor 2 , slightly above .8 .

Since white identity politics represent a meaningful shift in how some whites view themselves and the political world (see Jardina 2019), we also examined the relationship between WPD and measures of white identity (WI) and white consciousness (WC) (refer to online appendix $\mathrm{C}$ for full question wording). According to Jardina (2019), whites who strongly identify with their race and have a strong sense of racial group solidarity are more likely to "embrace their privileged status" in ways that maintain racial inequality, and likewise harbor exclusionary attitudes. Thus, WPD should be related to measures of WI and WC but, as Jardina (2019) found, they should be distinct. Although these constructs belong to the 
same family, WPD (like racial resentment) is an attitude, not an identity or form of group consciousness. In our initial analysis, we find that WPD and WI are weakly correlated $(\mathrm{r}=-.0053)$ but that WPD and WC are more strongly correlated $(\mathrm{r}=.5198)$. To be sure that WPD is distinct from WI and WC, we nevertheless included them in the factor analysis.

The right side of table 2 investigates whether WI and WC are distinct from WPD and RR (only available in the 2018 data). If white identity and consciousness are indistinguishable from racial attitudes, either WPD or RR, we would expect them to load onto the same factors. The results suggest this is not the case. Neither WI nor WC load onto the same factor as either WPD or RR at the conventional .4 standard, indicating they are distinct scales. For interested readers, we also considered social dominance orientation (SDO), a predisposition towards group-based hierarchy (Pratto et al. 1994), as well as hostile sexism (HS), a belief that women are trying to control men (Cassese and Holman 2019; Schaffner 2021), as both are related to racial attitudes and are increasingly important in understanding political preferences. As shown in online appendix $\mathrm{C}$, the SDO and HS items do not load onto the same factor as WPD, and from the results in online appendix $\mathrm{D}$, the effects for WPD do not substantively change when controlling for SDO or HS.

Given the modest number of cases in our analyses, we also replicated some of our results (when items were available) using a question similar to the first item in the WPD scale from the 2018 CCES and 2020 CES (formerly the CCES) common content. In online appendix E, we report the results from these analyses featuring approximately 35,000 whites to rule out that our results are due to a relatively small number of cases. In each of the analyses, we replicated the findings for WPD and RR. In sum, by using a single item similar to an item in the WPD scale, our basic findings regarding the importance of WPD are corroborated in a large- $\mathrm{N}$ analysis.

Having established that white privilege denial is distinct from other prominent measures and correlates of racial attitudes and identity, in the following sections we examine whether, and how, it informs a variety of important political attitudes including evaluations of presidential candidates, presidents, and public policy. In the following models, we include these other measures of racial attitudes, identity, and consciousness to ensure that the reported effects of WPD matter beyond the usual suspects.

\section{The Manifestation of White Privilege Denial in American Politics}

Race is a defining feature of the American party system (Bowler and Segura 2012; Carmines and Stimson 1989; Hutchings and Valentino 2004; Kinder and Sanders 1996; Mendelberg 2001; Parker and Barreto 2013; Philpot 2007). The differences in the racial groups that make up party coalitions and the positions taken by parties on racial issues have forged party images or reputations reflective of these differences (Carmines and Stimson 1989; Heit and Nicholson 2016; Philpot 2007) and these reputations shape evaluations of parties and politicians (Carmines and Stimson 1989; Hutchings and Valentino 2004; Jardina 2019; Kinder and Sanders 1996; Mendelberg 2001; Nicholson 2005; Reny, Collingwood, and Valenzuela 2019; Sheagley, Chen, and Farhart 2017; Tesler 2016; Tesler and Sears 2010; Valentino, Hutchings, and White 2002; Valentino, Neuner, and Vandenbroek 2018; Sides, Tesler and Vavreck 2019; Segura and Valenzuela 2010). Similarly, racial attitudes are a primary ingredient in explaining public support for a variety of policy proposals (Brader, Valentino, and Suhay 2008; Gilens 1999; Jardina 2019; Kinder and Sanders 1996; Pérez 2010; 2016; Tesler 2012).

White privilege denial enables whites to dismiss how they benefit from racism, maintain the legitimacy of the racial system, and ultimately eschew responsibility for addressing racial inequalities. As a way of maintaining positive racial intergroup comparisons (positive distinctiveness), those in denial of white privilege are likely to align themselves with political actors and embrace public policies that will maintain the racial status quo. Given the clear party differences on the question of race, white privilege denial is likely to manifest itself in support for (opposition towards) Republican (Democratic) politicians. In online appendix $\mathrm{F}$, we report findings showing that white privilege denial has a positive and significant association with affective polarization towards Republicans at the detriment of Democrats.

Since racial attitudes also shape public opinion on a variety of policy issues (Gilens 1999; Jardina 2019; Kinder and Sanders 1996; Tesler 2016), we advance this research by looking at a host of public policies. Although some of the issues we examine are explicitly racial by design (e.g., affirmative action), others have become racialized, the process whereby a race-neutral policy such as health care becomes tied to racial group images through the media and elite discourse (Gilens 1999; Tesler 2015). By looking at white privilege denial, we can examine whether notions of unearned white advantage, a threat to the positive distinctiveness of whites, is associated with racialized policy attitudes. For racial and racialized policies, we expect white privilege denial to be associated with greater support for racially conservative positions that promote, or at least do not undermine, the higher status of whites. For instance, we expect those higher in denial to be more likely to oppose affirmative action, immigration, and oppose NFL player protests against racial injustice.

In all our analyses, we control for a variety of alternative explanations. Foremost among our controls is racial resentment, the most widely used measure of white racial attitudes in political science. In addition to 
racial resentment, we also control for white identity and white consciousness (2018 only) since Jardina (2019) found they were relevant to explaining policy attitudes that affect whites as a group. By including a thorough set of controls, we can be confident that the results we obtain for white privilege denial are not simply standing in for omitted variables. In other words, we can examine the effects of white privilege denial beyond existing explanations. Nevertheless, given the observational nature of our data we are limited to establishing associations between racial attitudes. Future research is necessary to examine causal relationships.

\section{White Privilege Denial and Candidate Evaluation}

Race has played an important role in American elections, and it was especially salient in the 2016 presidential race (Abramowitz and McCoy 2019; Reny, Collingwood, and Valenzuela 2019; Sides, Tesler, and Vavreck 2019). Although racial animus is central to understanding vote choice in the 2016 election, our inquiry advances understanding of it (and perhaps candidate evaluations more generally) by examining the role of white privilege denial. Since the denial of white privilege permits whites to retain a positive self-concept by maintaining positive distinctiveness, a favorable comparison between their racial group and people of color, we expect whites in greater denial to rate Trump more favorably in relation to Clinton.

To capture candidate evaluations, we rely on feeling thermometers, measures of how warmly a person feels toward a candidate that ranges on a scale from zero to one hundred. We created the dependent variable by subtracting thermometer ratings for Clinton from Trump so that the scores range from -100 to 100 in which higher values reflect greater relative affect for Trump. In online appendix G, we present an alternative version of this analysis where the feeling thermometers for both candidates are each measured separately. In keeping with Trump's racial campaign rhetoric and the long-standing racial differences between the parties, we expect higher levels of WPD to produce warmer feelings toward Trump relative to Clinton. Put differently, we expect that whites who acknowledge White privilege to have more positive feelings towards Clinton relative to Trump. Although we also expect RR to similarly shape candidate evaluation in this manner, it of course captures the effects of outgroup animus whereas WPD captures the desire for whites to maintain positive distinctiveness (and feel good about the ingroup). We also include controls for party identification, ideology, and demographic characteristics. All variables have been rescaled from zero to one to aid in the comparison of coefficients.

Table 3 displays the results of an OLS regression analysis with Huber-White standard errors looking at the effects of WPD and RR on relative evaluations of
Table 3

The effect of white privilege denial on relative affect for Trump over Clinton in the 2016 election

\begin{tabular}{lc}
\hline & $\begin{array}{c}\text { Candidate } \\
\text { Differential }\end{array}$ \\
\hline White Privilege Denial (WPD) & $37.569^{\star}$ \\
& $(9.99)$ \\
Racial Resentment (RR) & $48.331^{*}$ \\
& $(10.56)$ \\
Conservative & $29.246^{*}$ \\
& $(11.04)$ \\
Republican & $82.558^{*}$ \\
& $(8.16)$ \\
Female & -2.687 \\
& $(3.99)$ \\
Age & $18.383^{\star}$ \\
& $(8.37)$ \\
Income & -28.235 \\
& $(17.29)$ \\
Education & -0.718 \\
& $(7.5)$ \\
Constant & $-103.682^{*}$ \\
& $(8.21)$ \\
R-Squared & 0.658 \\
$\mathrm{~N}$ & 399 \\
BIC & 4158 \\
\hline * $\mathrm{p}<.05$ & \\
Note: The candidate differential ranges from -100 to 100 \\
where greater values indicate higher relative support for \\
Trump over Clinton and was estimated using OLS. \\
\end{tabular}

the 2016 presidential candidates. We find that WPD is a strong, significant predictor of favoring Trump over Clinton, controlling for RR. The effect of RR, however, appears to be somewhat larger than WPD so we looked at the thermometer ratings for each candidate separately (refer to online appendix G). The models in online appendix G suggest that WPD appears to be more strongly related to negative affect towards Clinton whereas RR appears to be more strongly associated with positive affect towards Trump. These results make sense considering what we know about the candidates' campaigns. Whereas Trump emphasized racial animus, Clinton's campaign stressed themes of racial inequality with references to "systemic racism" and racial bias in policing (see Sides, Tesler, and Vavreck 2019). In online appendix H, we also examine whether the effects of WPD and RR on candidate evaluations (and other outcome variables) are moderated by ideology or party identification, but we found inconsistent interaction effects.

\section{White Privilege Denial and Presidential Approval}

We conducted similar analyses of presidential approval for Obama in 2016 and Trump in 2018 to provide further insight into how WPD informs evaluations of political 
figures. Like the previous analysis, we expect whites higher in white privilege denial to be less approving of President Obama (a Democrat) and more approving of President Trump (a Republican). Again, we expect a similar pattern of results for racial resentment but for different reasons. Whereas respondents high in RR are more likely to support or oppose presidents because of outgroup animus, those high in WPD wish to align themselves with presidents who do not challenge the legitimacy of the racial hierarchy to preserve favorable intergroup comparisons. For ease of presentation, presidential approval is coded one for approval and zero for disapproval (refer to online appendix I for ordered probit results).

Table 4 presents the results of a probit analysis investigating the effects of WPD on presidential approval for Obama and Trump. Consistent with our expectations, we find that WPD is associated with approval of President Trump and disapproval of President Obama. When controlling for other racial constructs in 2018, the effect of WPD remains robust while the effect of RR is rendered

\begin{tabular}{|c|c|c|c|}
\hline & $\begin{array}{l}\text { Obama } \\
2016\end{array}$ & $\begin{array}{l}\text { Trump } \\
2018(1)\end{array}$ & $\begin{array}{l}\text { Trump } \\
2018(2)\end{array}$ \\
\hline $\begin{array}{l}\text { White Privilege } \\
\text { Denial (WPD) }\end{array}$ & $\begin{array}{c}-1.161^{*} \\
(0.39)\end{array}$ & $\begin{array}{l}1.422^{*} \\
(0.36)\end{array}$ & $\begin{array}{l}1.426^{*} \\
(0.37)\end{array}$ \\
\hline $\begin{array}{l}\text { Racial Resentment } \\
\quad \text { (RR) }\end{array}$ & $\begin{array}{c}-1.177^{\star} \\
(0.48)\end{array}$ & $\begin{array}{l}1.020^{*} \\
(0.46)\end{array}$ & $\begin{array}{l}0.931 \\
(0.49)\end{array}$ \\
\hline White Identity (WI) & -- & -- & $\begin{array}{l}0.122 \\
(0.28)\end{array}$ \\
\hline $\begin{array}{l}\text { White } \\
\text { Consciousness } \\
\text { (WC) }\end{array}$ & -- & -- & $\begin{array}{r}0.347 \\
(.37)\end{array}$ \\
\hline Conservative & $\begin{array}{c}-1.651^{*} \\
(0.47)\end{array}$ & $\begin{array}{l}1.763^{*} \\
(0.45)\end{array}$ & $\begin{array}{l}1.691^{*} \\
(0.45)\end{array}$ \\
\hline Republican & $\begin{array}{c}-2.609^{*} \\
(0.33)\end{array}$ & $\begin{array}{l}2.252^{*} \\
(0.32)\end{array}$ & $\begin{array}{l}2.238^{*} \\
(0.32)\end{array}$ \\
\hline Female & $\begin{array}{c}-0.162 \\
(0.17)\end{array}$ & $\begin{array}{c}-0.313 \\
(0.17)\end{array}$ & $\begin{array}{c}-0.327 \\
(0.18)\end{array}$ \\
\hline Age & $\begin{array}{c}-0.774^{*} \\
(0.36)\end{array}$ & $\begin{array}{l}0.141 \\
(0.39)\end{array}$ & $\begin{array}{l}0.182 \\
(0.40)\end{array}$ \\
\hline Income & $\begin{array}{l}0.279 \\
(0.81)\end{array}$ & $\begin{array}{l}0.333 \\
(0.47)\end{array}$ & $\begin{array}{l}0.370 \\
(0.47)\end{array}$ \\
\hline Education & $\begin{array}{l}0.319 \\
(0.32)\end{array}$ & $\begin{array}{l}0.387 \\
(0.33)\end{array}$ & $\begin{array}{l}0.431 \\
(0.35)\end{array}$ \\
\hline Constant & $\begin{array}{c}-3.380^{\star} \\
(0.42)\end{array}$ & $\begin{array}{c}-3.822^{*} \\
(0.44)\end{array}$ & $\begin{array}{c}-3.940^{*} \\
(0.43)\end{array}$ \\
\hline $\mathrm{N}$ & 537 & 582 & 573 \\
\hline BIC & 368.2 & 334.6 & 343.1 \\
\hline
\end{tabular}

statistically insignificant and neither WI nor WC are significant predictors.

Figure 3 depicts the changes in probability of presidential approval when moving from the minimum to the maximum levels of each racial attitude while holding all other variables constant at their mean values. We use the estimates for Trump approval (model 1) without WI and WC to maintain comparability with the Obama estimates. The probability of Obama approval decreases by .437 when moving from the lowest to the highest level of WPD and .444 when looking at the same shift across RR. As for Trump approval, the probability of approval increases by .491 when moving from minimum to maximum WPD whereas the increase is somewhat smaller, .354, for RR. Although WPD and RR have comparable effects on Obama approval, WPD appears to have a stronger association than RR on approval of President Trump. Although speculative, the larger effect of racial resentment in 2016 might reflect the greater amount of racial rhetoric that defined Trump's 2016 campaign (see Sides, Tesler, and Vavreck 2019).

As mentioned, in analyses presented in online appendix F, we also examined whether WPD contributed to a measure of affective polarization that captured warmth towards the Republican Party relative to the Democratic Party. Using the same approach for candidate evaluations and presidential approval, we found that WPD is significantly associated with pro-Republican affective polarization in both 2016 and 2018.

\section{White Privilege Denial and Policy Attitudes}

We present three sets of analyses of policy attitudes. We begin with a broad sweep, looking at a variety of policy areas scholars have recognized as racial or racialized including affirmative action and social welfare, but also a more contemporary racialized issue, the Affordable Care Act. A second set of analyses focuses on immigration and refugee policies, the foremost racialized issues of the Trump presidency (at least at the time of our surveys). The final set of analyses focuses on symbolic racial issues including the birther conspiracy theory and NFL players "taking a knee" in protest of racial injustice.

White privilege denial should be associated with opposition to racially egalitarian programs and support for more exclusionary policies. In this respect, the broad reach of white privilege denial should be much like racial resentment. Motivated by the desire to maintain positive distinctiveness, white privilege denial involves group differentiation (which necessarily includes both ingroup and outgroup considerations) and thus supporting public policy that maintains the advantaged position of whites relative to people of color. Motivated by outgroup animus, racial resentment is about opposing policies that help racial and ethnic minorities. Since we examine racial and 


\section{Figure 3}

\section{Predicted probabilities of the effects of racial attitudes on presidential approval}
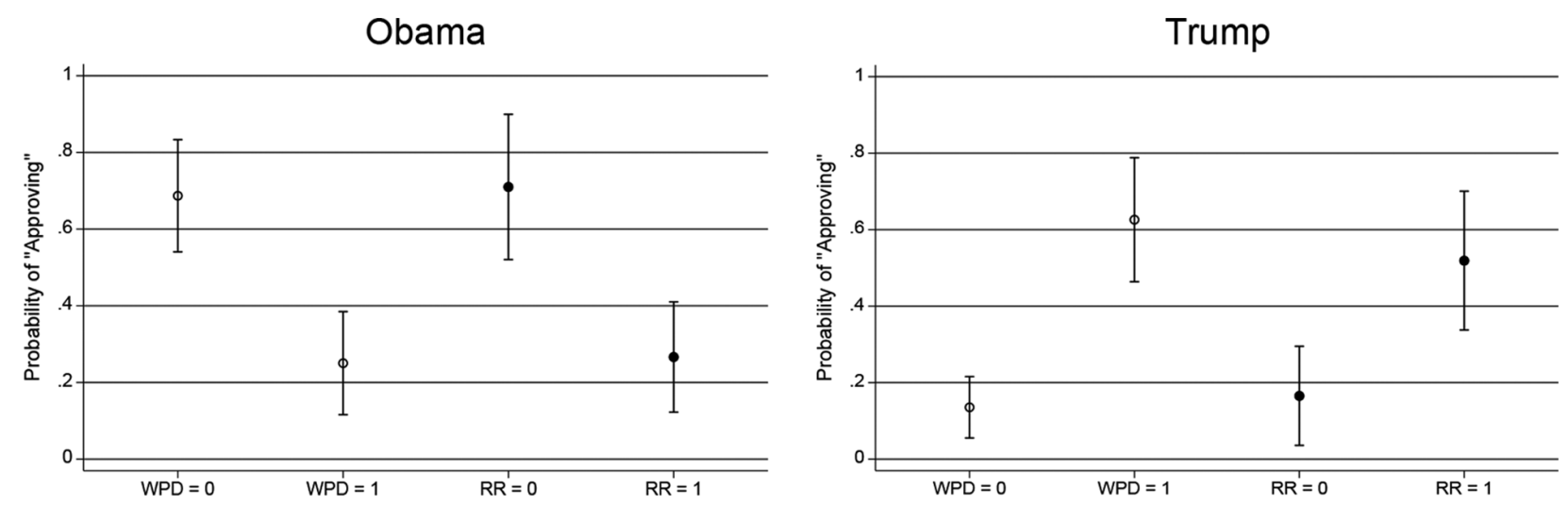

racialized policy, the scope of white privilege denial and racial resentment should be largely the same. In contrast, white identity and white consciousness will be more limited, only informing opinion on policies perceived to benefit whites since, according to Jardina (2019), white identity and consciousness motivate support for policies that are perceived to protect whites but not policies that are perceived to help racial and ethnic minorities.

The question wording for all items is available in online appendix J. For all the dependent variables, policy attitudes are coded such that higher values reflect greater support for racially conservative opinions.

\section{White Privilege Denial and Racial(ized) Policy Attitudes}

We begin with racialized policy areas. Foremost among the policies we examine are affirmative action and social welfare policy. Despite critics (Pratto et al. 1994; Sniderman and Tetlock 1986), a wealth of studies show that racial animus increases opposition to affirmative action (Kinder and Sanders 1996; Tarman and Sears 2005) and social welfare spending (Gilens 1999; Kinder and Sanders 1996; Rabinowitz et al. 2009). We also examine racial attitudes toward the Affordable Care Act (ACA) since Tesler (2012) found that whites high in racial resentment are more likely to oppose the ACA, a policy strongly associated with President Obama. Whereas those who are high in racial resentment will oppose these programs because they hold negative stereotypes of Blacks and find them undeserving, those high in white privilege denial are likely to oppose these programs because they undermine the advantaged position of whites in employment, economic status, and health care coverage, a threat to the positive distinctiveness of whites.

Table 5 presents the results of the analyses of racialized policies. As expected, WPD is strongly associated with

increased opposition to affirmative action, social welfare spending, and the Affordable Care Act. Among the other racial constructs, only $\mathrm{RR}$ helps explain attitudes on these racialized policies. Our results for WI and WC replicate Jardina's (2019) analysis since neither are significant predictors of white opposition to affirmative action or welfare spending. This is not unexpected, however, since she found that white identity and consciousness are relevant to understanding policy that is perceived to affect whites, not racial outgroups (Jardina 2019).

Figure 4 depicts predicted probability changes for the strongest opposition to affirmative action, social welfare spending, and support for repealing the Affordable Care Act moving from the lowest to the highest levels of WPD and RR. The probability of choosing the strongest opposition to affirmative action increases by .45 when moving from the minimum to the maximum of WPD. The change in probability is smaller, an increase of .35, when making the same comparison across levels of RR. For social welfare spending, the probability of expressing the strongest opposition increases by .15 when moving from the lowest to the highest value of WPD. In contrast, moving from the lowest to the highest value of RR produces an increase of .08 in expressing the strongest opposition. Lastly, the probability of strongly supporting the repeal of the ACA increased by .20 when moving from the minimum to the maximum level of WPD and .44 when moving from the lowest to the highest levels of RR.

In sum, white privilege denial and racial resentment both matter for understanding attitudes towards racialized policy areas but the effect sizes varied. For affirmative action and social welfare attitudes, WPD may have a more pronounced effect than $R R$, suggesting that opposition to these programs is more strongly associated with how they threaten the positive distinctiveness of whites by undermining their advantaged position rather than anti-Black 
Table 5

The effect of white privilege denial on racialized policy attitudes

\begin{tabular}{|c|c|c|c|}
\hline & Affirmative Action & Welfare Spending & Repeal ACA \\
\hline White Privilege Denial (WPD) & $\begin{array}{l}1.598^{*} \\
(0.27)\end{array}$ & $\begin{array}{l}1.108^{*} \\
(0.26)\end{array}$ & $\begin{array}{c}0.586^{*} \\
(0.3)\end{array}$ \\
\hline Racial Resentment (RR) & $\begin{array}{l}1.279^{*} \\
(0.29)\end{array}$ & $\begin{array}{c}0.720^{*} \\
(0.31)\end{array}$ & $\begin{array}{l}1.382^{*} \\
(0.37)\end{array}$ \\
\hline White Identity (WI) & $\begin{array}{l}0.046 \\
(0.16)\end{array}$ & $\begin{array}{l}0.002 \\
(0.16)\end{array}$ & $\begin{array}{c}-0.218 \\
(0.22)\end{array}$ \\
\hline White Consciousness (WC) & $\begin{array}{c}-0.213 \\
(0.21)\end{array}$ & $\begin{array}{c}-0.279 \\
(0.22)\end{array}$ & $\begin{array}{c}0.568 \\
(0.3)\end{array}$ \\
\hline Conservative & $\begin{array}{c}0.858^{*} \\
(0.28)\end{array}$ & $\begin{array}{l}1.367^{*} \\
(0.29)\end{array}$ & $\begin{array}{l}0.788^{*} \\
(0.38)\end{array}$ \\
\hline Republican & $\begin{array}{l}0.061 \\
(0.22)\end{array}$ & $\begin{array}{l}0.184 \\
(0.22)\end{array}$ & $\begin{array}{l}1.351^{*} \\
(0.28)\end{array}$ \\
\hline Female & $\begin{array}{c}-0.005 \\
(0.1)\end{array}$ & $\begin{array}{l}0.019 \\
(0.09)\end{array}$ & $\begin{array}{c}-0.188 \\
(0.14)\end{array}$ \\
\hline Age & $\begin{array}{c}-0.157 \\
(0.2)\end{array}$ & $\begin{array}{l}0.073 \\
(0.21)\end{array}$ & $\begin{array}{l}0.049 \\
(0.32)\end{array}$ \\
\hline Income & $\begin{array}{l}0.720^{*} \\
(0.23)\end{array}$ & $\begin{array}{l}1.138^{*} \\
(0.22)\end{array}$ & $\begin{array}{c}-0.497 \\
(0.34)\end{array}$ \\
\hline Education & $\begin{array}{c}-0.182 \\
(0.18)\end{array}$ & $\begin{array}{l}0.222 \\
(0.18)\end{array}$ & $\begin{array}{l}0.263 \\
(0.26)\end{array}$ \\
\hline Cut 1 & $\begin{array}{c}-0.333 \\
(0.22)\end{array}$ & $\begin{array}{c}0.554^{*} \\
(0.21)\end{array}$ & \\
\hline Cut 2 & $\begin{array}{l}0.332 \\
(0.21)\end{array}$ & $\begin{array}{l}1.489^{*} \\
(0.21)\end{array}$ & \\
\hline Cut 3 & $\begin{array}{c}0.974^{*} \\
(0.21)\end{array}$ & $\begin{array}{c}2.821^{*} \\
(0.22)\end{array}$ & \\
\hline Cut 4 & $\begin{array}{c}2.004^{*} \\
(0.23)\end{array}$ & $\begin{array}{c}3.738^{*} \\
(0.23)\end{array}$ & \\
\hline Cut 5 & $\begin{array}{c}2.385^{\star} \\
(0.23)\end{array}$ & & \\
\hline Cut 6 & $\begin{array}{c}2.740^{*} \\
(0.24)\end{array}$ & & \\
\hline Constant & & & $\begin{array}{c}-2.590^{*} \\
(0.32)\end{array}$ \\
\hline $\mathrm{N}$ & 584 & 583 & 584 \\
\hline $\mathrm{BIC}$ & 1786.2 & 1537 & 516.3 \\
\hline
\end{tabular}

* $p<.05$

Note: Affirmative Action ranges from 1 (Strongly Favor) to 7 (Strongly Oppose) and was estimated using ordered probit. Welfare Spending ranges from 1 (Greatly increase) to 5 (Greatly decrease) and was estimated using ordered probit. Repeal $A C A$ is binary $(0=$ Oppose, 1 = Support) and was estimated using probit.

affect. Attitudes towards the ACA, however, appear to be more strongly associated with racial animus, supporting Tesler's finding (2012) that its racialization is primarily due to its strong association with President Obama.

\section{White Privilege Denial and Immigration Policy Attitudes}

The second set of analyses focuses on immigration and refugee policy, the defining racialized policy issues of the Trump presidency (at least prior to the death of George Floyd). Trump made immigration a key issue during his 2016 campaign as well as during his presidency when he advanced these issues through high-profile executive orders suspending visas from Muslim-majority countries, increasing border security, and restricting the number of refugees allowed into the United States. Although immigration attitudes are informed by a variety of factors (Hainmueller and Hopkins 2014), anti-Latino sentiment is central to explaining opposition to immigration in the United States (Abrajano and Hajnal 2015; Brader, Valentino, and Suhay 2008; Nicholson 2005; Pérez 2010, 2016; Schildkraut 2010; Valentino, Brader, and Jardina 2013). Given that Latinos are the face of contemporary immigration in the United States (Valentino, Brader, and Jardina 2013), scholars have largely side-stepped racial resentment given its focus on Blacks. Nevertheless, racial resentment likely taps into a broader prejudice, ethnocentrism (Kinder and Kam 2009), suggesting it is also likely to shape immigration policy attitudes. Yet, even so, any measure of outgroup animus is inherently limited in 


\section{Figure 4}

\section{Predicted probabilities of racialized policy attitudes}

Affirmative Action

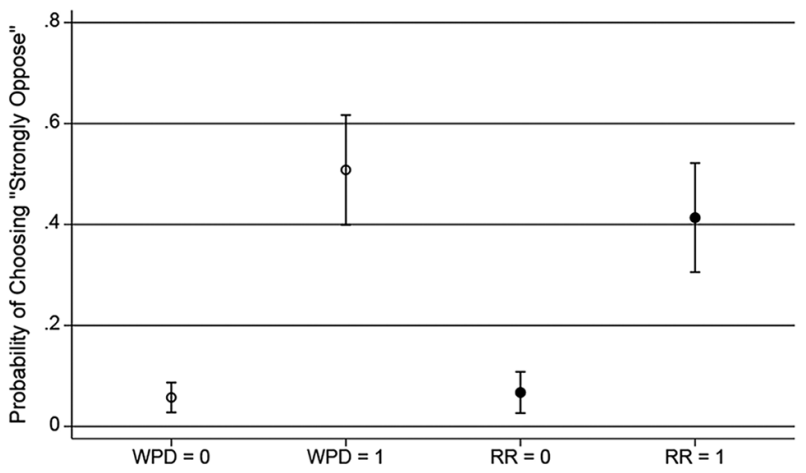

Welfare Spending

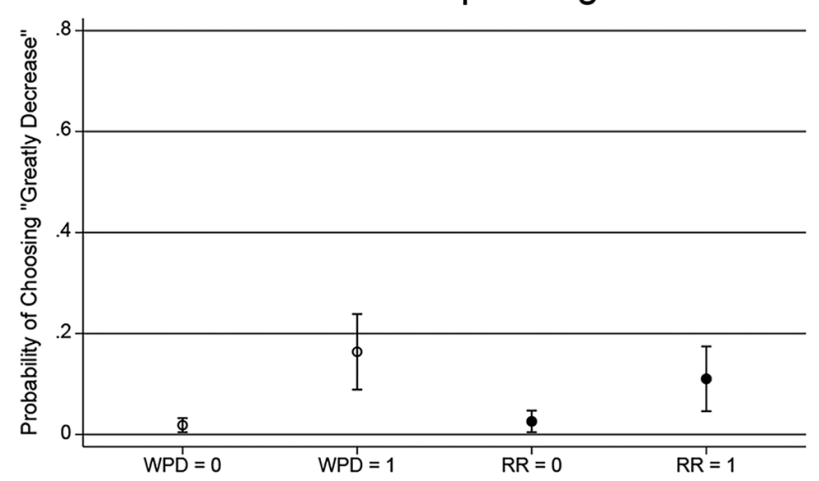

Repeal ACA

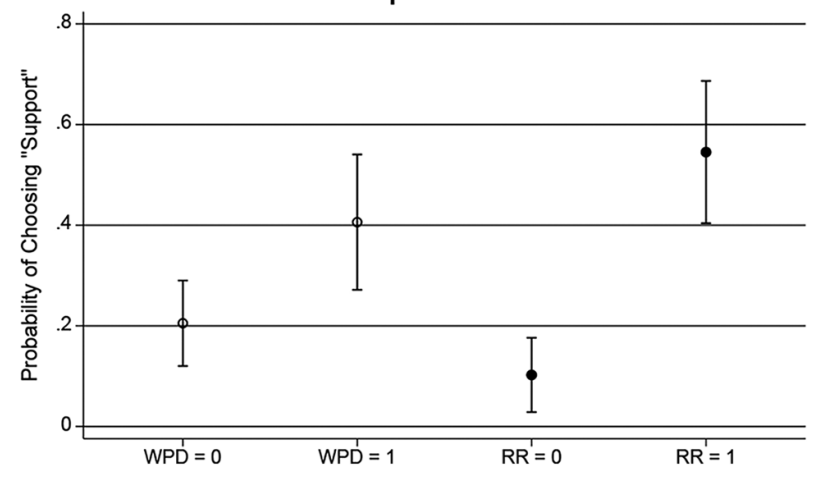

explaining immigration attitudes since immigration, and the threat it represents, has implications for the dominant position of whites. Our expectation is that those who seek positive distinctiveness for their group in the denial of white privilege will be more likely to oppose immigration in a variety of forms.

To evaluate the role of white privilege denial on opinion towards immigration and refugee policy we proceed with three sets of analyses. The first considers preferences on five immigration laws combined into a single index ranging from 0 to 1 (Chronbach's $\alpha=.84$ ). The index includes items about increasing border security and building a wall between the United States and Mexico border, eliminating the visa lottery and family-based migration, granting legal status to DACA children, fining police departments that do not report illegal immigrants, and sending to prison deportees that reenter the United States. The second analysis examines a single, broad question about whether "the number of immigrants from foreign countries who are permitted to the U.S. to live" should be increased or decreased. Finally, the third analysis examines an item asking respondents whether they supported President
Trump's executive order to prohibit "Syrian refugees from entering the country" and to "ban immigrants from Iran, Sudan, Yemen, Syria, and Libya." Full question wording is available in online appendix J. Variables are rescaled from 0 to 1 and coded such that higher values reflect exclusionary attitudes.

Table 6 presents the results of the analyses. In each model, controlling for racial resentment, WPD has a consistently positive and statistically significant effect on support for anti-immigrant and anti-refugee policy. Despite focusing on Blacks, whites who are higher in RR also consistently hold exclusionary attitudes towards immigrants and refugees, a finding that suggests the measure captures a broader prejudice towards people of color. Lastly, table 6 shows that WI has a positive and statistically significant effect on immigration levels but not the immigration laws index nor the refugee order. The opposite pattern is found for WC. It is significantly associated with the immigration laws index and refugee executive order but not immigration levels.

Figure 5 presents the predicted probabilities of choosing the most racially conservative response for our analysis of 
Table 6

The effect of privilege denial on immigration and refugee policy attitudes

\begin{tabular}{|c|c|c|c|}
\hline & Immigration Laws Index & Immigration Levels & Refugee Order \\
\hline White Privilege Denial (WPD) & $\begin{array}{l}0.253^{*} \\
(0.05)\end{array}$ & $\begin{array}{c}0.979^{*} \\
(0.24)\end{array}$ & $\begin{array}{l}1.301^{*} \\
(0.33)\end{array}$ \\
\hline Racial Resentment (RR) & $\begin{array}{l}0.247^{*} \\
(0.06)\end{array}$ & $\begin{array}{l}1.395^{*} \\
(0.28)\end{array}$ & $\begin{array}{l}1.709^{*} \\
(0.42)\end{array}$ \\
\hline White Identity (WI) & $\begin{array}{c}0.048 \\
(0.03)\end{array}$ & $\begin{array}{l}0.365^{\star} \\
(0.17)\end{array}$ & $\begin{array}{c}-0.119 \\
(0.26)\end{array}$ \\
\hline White Consciousness (WC) & $\begin{array}{c}0.142^{*} \\
(0.04)\end{array}$ & $\begin{array}{c}0.021 \\
(0.23)\end{array}$ & $\begin{array}{l}1.039^{*} \\
(0.31)\end{array}$ \\
\hline Conservative & $\begin{array}{l}0.275^{*} \\
(0.06)\end{array}$ & $\begin{array}{l}1.229^{\star} \\
(0.29)\end{array}$ & $\begin{array}{l}0.392 \\
(0.4)\end{array}$ \\
\hline Republican & $\begin{array}{l}0.201^{*} \\
(0.05)\end{array}$ & $\begin{array}{c}-0.043 \\
(0.22)\end{array}$ & $\begin{array}{l}1.347^{*} \\
(0.31)\end{array}$ \\
\hline Female & $\begin{array}{c}-0.061^{*} \\
(0.02)\end{array}$ & $\begin{array}{l}0.156 \\
(0.1)\end{array}$ & $\begin{array}{c}-0.02 \\
(0.15)\end{array}$ \\
\hline Age & $\begin{array}{l}0.169^{*} \\
(0.04)\end{array}$ & $\begin{array}{c}0.29 \\
(0.22)\end{array}$ & $\begin{array}{l}1.060^{*} \\
(0.34)\end{array}$ \\
\hline Income & $\begin{array}{c}-0.017 \\
(0.05)\end{array}$ & $\begin{array}{c}-0.17 \\
(0.24)\end{array}$ & $\begin{array}{c}-0.299 \\
(0.36)\end{array}$ \\
\hline Education & $\begin{array}{c}0.058 \\
(0.04)\end{array}$ & $\begin{array}{c}-0.064 \\
(0.18)\end{array}$ & $\begin{array}{c}0.244 \\
(0.26)\end{array}$ \\
\hline Cut 1 & & $\begin{array}{l}0.282 \\
(0.2)\end{array}$ & $\begin{array}{l}3.239^{*} \\
(0.36)\end{array}$ \\
\hline Cut 2 & & $\begin{array}{l}1.242^{*} \\
(0.2)\end{array}$ & \\
\hline Cut 3 & & $\begin{array}{l}2.630^{*} \\
(0.22)\end{array}$ & \\
\hline Cut 4 & & $\begin{array}{l}3.133^{*} \\
(0.23)\end{array}$ & \\
\hline Constant & $\begin{array}{c}-0.175^{\star} \\
(0.04)\end{array}$ & & \\
\hline $\begin{array}{l}\text { R-Squared } \\
\text { N } \\
\text { BIC }\end{array}$ & $\begin{array}{l}0.703 \\
567\end{array}$ & 553 & 581 \\
\hline $\mathrm{BIC}$ & -94.4 & 1404.4 & 431.9 \\
\hline
\end{tabular}

Figure 5

Predicted probabilities for immigration levels and refugee policy attitudes
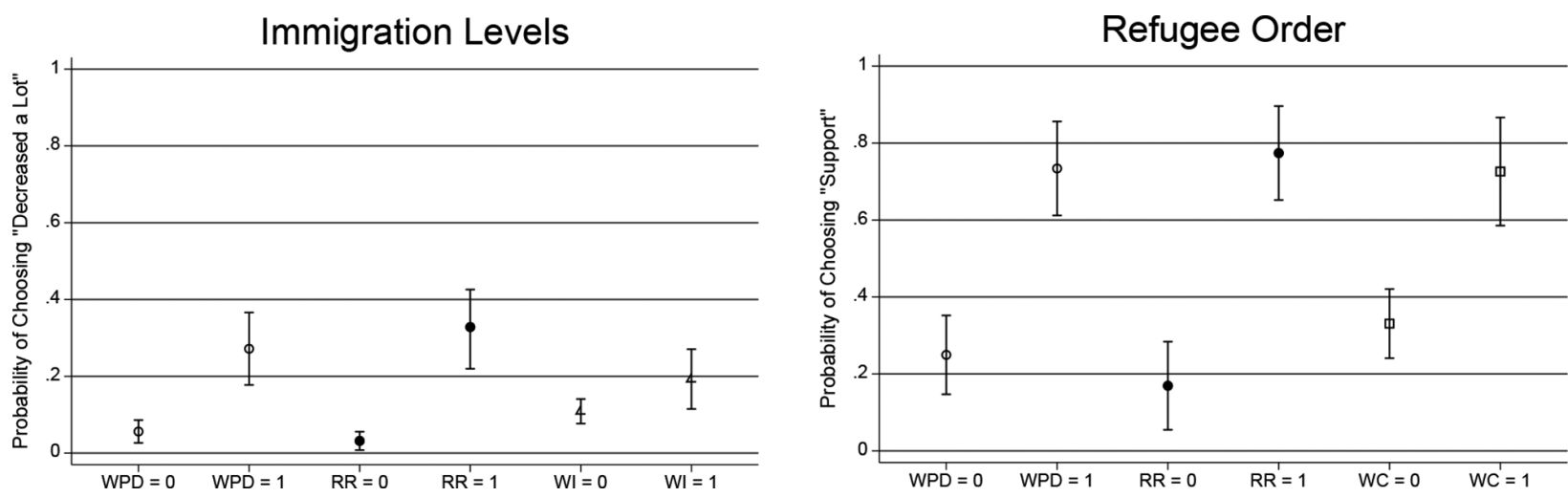
opinion on immigration levels and support for President Trump's executive order on restricting refugees. In looking at immigration levels, we examined the predicted probability of choosing "Decreased a lot." The probability of this response increases by .22 when moving from the lowest to highest level of WPD and increases .29 when comparing the lowest to the highest levels of RR. Lastly, moving from the lowest to the highest value of WI increases the probability of "Decreased a lot" by .084 . In the analysis of attitudes towards the refugee executive order, the change from the lowest to the highest value of WPD increased support by .48. whereas the same change in RR produced an increase of .60. Furthermore, we considered the shift from lowest to the highest value of WC, which produces a change in probability of "Decreased a lot" by .39. Taken together, both measures of racial attitudes (WPD and RR) and racial solidarity (WI and WC) play an important role informing opinion on these policies with a slightly larger effect for RR suggesting that outgroup animus might play a larger role in explaining immigration and refugee policy attitudes.

\section{White Privilege Denial and Symbolic Political Attitudes}

In the final set of analyses, we examine whether white privilege denial informs opinion on two symbolic political issues imbued with race; the birther conspiracy theory and NFL players taking a knee in protest of racial injustice. The birther rumor, the claim that President Obama was born outside the United States, is perhaps the most highprofile conspiracy theory of the Obama era. Although partisanship plays a central role in birtherism (Duran, Nicholson, and Dale 2017; Jardina and Traugott 2019; Miller, Saunders, and Farhart 2016), it is also animated by racial animus (Jardina and Traugott 2019; Tesler and Sears 2010). We expect those higher in WPD to be inclined to find a Black president illegitimate since it threatens the advantaged position of whites in the political system to have a Black president.

NFL players kneeling during the national anthem in protest of racial injustice is an explicitly racial matter. Colin Kaepernick, who led the movement, became the face of the controversial protests and the league's mostdisliked player (Rovell 2016). In looking at opposition to the protests, we expect those in denial of white privilege to define what is "appropriate" behavior through the lens of their own experience, discounting the lived experiences of Blacks. In addition, acknowledgement of systemic racial injustice challenges white advantage in the racial justice system, a threat to the positive distinctiveness of whites.

Table 7 presents the results of ordered probit analyses examining belief in the birther conspiracy theory and opposition to the NFL protests. We found WPD to be strongly associated with opposition to the NFL protests, as well as belief in the birther conspiracy. Racial resentment is

\begin{tabular}{|c|c|c|}
\hline & Anthem & Birther \\
\hline White Privilege Denial (WPD) & $\begin{array}{l}1.536^{*} \\
(0.32)\end{array}$ & $\begin{array}{l}0.859^{*} \\
(0.26)\end{array}$ \\
\hline Racial Resentment (RR) & $\begin{array}{l}1.445^{\star} \\
(0.37)\end{array}$ & $\begin{array}{c}0.592 \\
(0.33)\end{array}$ \\
\hline White Identity (WI) & $\begin{array}{c}-0.064 \\
(0.22)\end{array}$ & $\begin{array}{l}0.503^{*} \\
(0.18)\end{array}$ \\
\hline White Consciousness (WC) & $\begin{array}{c}0.607^{\star} \\
(0.29)\end{array}$ & $\begin{array}{l}1.116^{*} \\
(0.25)\end{array}$ \\
\hline Conservative & $\begin{array}{l}1.587^{\star} \\
(0.35)\end{array}$ & $\begin{array}{c}0.354 \\
(0.29)\end{array}$ \\
\hline Republican & $\begin{array}{l}0.969^{*} \\
(0.27)\end{array}$ & $\begin{array}{l}1.534^{\star} \\
(0.23)\end{array}$ \\
\hline Female & $\begin{array}{c}0.1 \\
(0.12)\end{array}$ & $\begin{array}{c}0.21 \\
(0.11)\end{array}$ \\
\hline Age & $\begin{array}{l}0.864^{*} \\
(0.24)\end{array}$ & $\begin{array}{c}0.111 \\
(0.24)\end{array}$ \\
\hline Income & $\begin{array}{c}0.189 \\
(0.32)\end{array}$ & $\begin{array}{c}-0.118 \\
(0.29)\end{array}$ \\
\hline Education & $\begin{array}{c}-0.126 \\
(0.21)\end{array}$ & $\begin{array}{c}-0.383 \\
(0.21)\end{array}$ \\
\hline Cut 1 & $\begin{array}{l}1.930 * \\
(0.27)\end{array}$ & $\begin{array}{l}2.180^{\star} \\
(0.25)\end{array}$ \\
\hline Cut 2 & $\begin{array}{l}2.432^{\star} \\
(0.28)\end{array}$ & $\begin{array}{l}3.149^{*} \\
(0.26)\end{array}$ \\
\hline Cut 3 & $\begin{array}{l}3.413^{*} \\
(0.3)\end{array}$ & $\begin{array}{l}4.097^{*} \\
(0.28)\end{array}$ \\
\hline Cut 4 & $\begin{array}{l}3.788^{\star} \\
(0.32)\end{array}$ & \\
\hline $\begin{array}{l}\mathrm{N} \\
\mathrm{BIC}\end{array}$ & $\begin{array}{c}584 \\
1042.6\end{array}$ & $\begin{array}{c}584 \\
1054.3\end{array}$ \\
\hline
\end{tabular}

also a significantly related to opposition to the protests, but it is statistically insignificant for explaining birtherism. This finding suggests whites are motivated to find a Black president illegitimate by way of maintaining positive distinctiveness than through racial animosity. We also find WC to be significantly related to these symbolic racial attitudes suggesting an important role for racial solidarity whereas WI matters for understanding birther attitudes but not the national anthem protests.

Figure 6 depicts predicted probabilities at the minimum and maximum levels of WPD and RR for the most extreme response categories, "Strongly Disapproving" of the NFL protests and responding "Definitely not" when asked if Obama was born in the United States. For birtherism, we find little change associated with racial attitudes, as the probability of believing Obama was "Definitely not" born in the United States increases by .05 when moving from the minimum to maximum levels of WPD and .03 


\section{Figure 6}

\section{Predicted probabilities of symbol political attitudes}
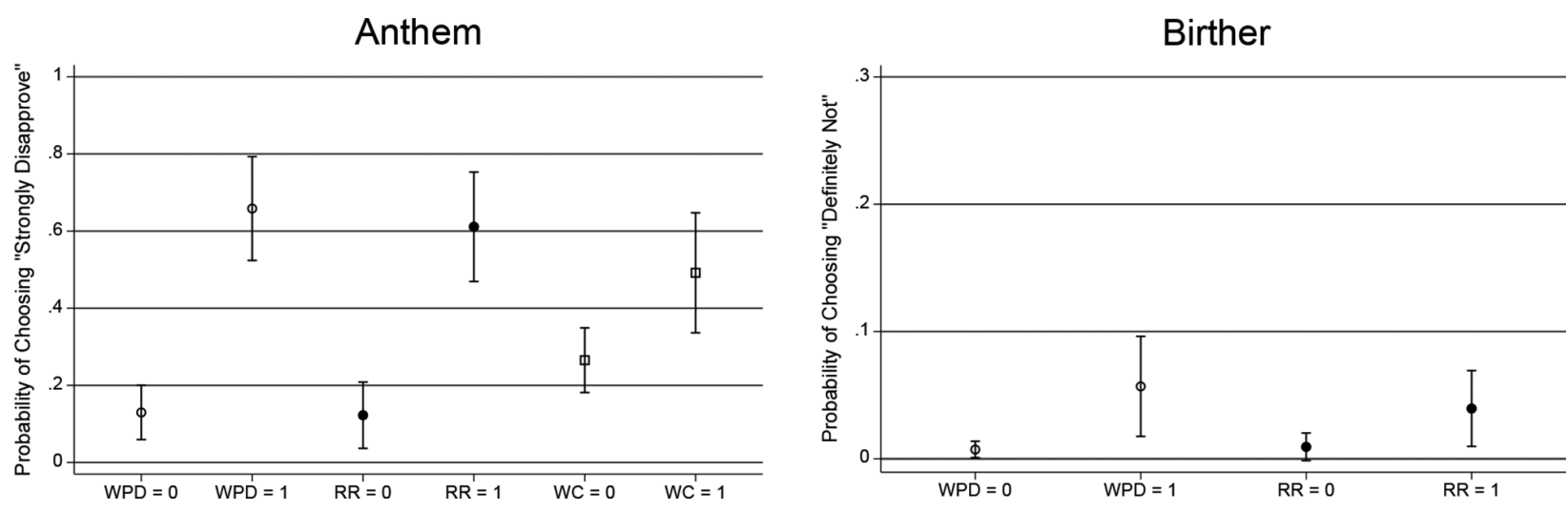

comparing the lowest to the highest levels of RR. Similarly, the same move across WI increases the probability of this response by .03 , and for WC we find a .09 increase in probability. In contrast, racial attitudes appeared to matter a great deal to the NFL protests. The probability of "Strongly Disapproving" increases by .53 when moving from the lowest to the highest levels of WPD and increases by .49 moving from the lowest to highest values of RR. WC also matters, increasing the probability of "Strongly Disapproving" by .23 moving from the lowest to the highest value. The larger effect sizes for attitudes towards the NFL protests suggest that it is more racialized than birtherism, a highly partisan conspiracy theory.

\section{Discussion and Conclusion}

The nature of racial attitudes among the American public is evolving. Where previous studies have focused on creating more palatable ways for whites to express racial animus toward minority groups, primarily Blacks, we examined white privilege as a means of focusing on white acceptance, or denial, of the unearned advantages that accompany whiteness. White privilege is a threat to the positive distinctiveness of whites since its acceptance means delegitimizing favorable intergroup comparisons with other racial groups. Denying white privilege preserves favorable comparisons to groups lower in the racial hierarchy.

Many whites fully acknowledge white privilege, but it is just as common to find whites who do not; nearly half express at least some denial and nearly one-third deny all the items on the WPD scale. Although related to other racial constructs, white privilege denial is distinct from other measures such as racial resentment (Kinder and Sanders 1996), social dominance orientation (Pratto et al. 1994), and hostile sexism (Cassese and Holman 2019; Schaffner 2021). As reported in Jardina (2019), we

also confirmed her findings that white privilege denial is distinct from measures of racial solidarity such as white identity and white group consciousness. Intergroup relations, especially involving race, are inherently complex phenomena, and each racial construct provides a different lens for examination. Despite the wealth of insightful instrumentation scholars have used for understanding race (Kinder 2013), we believe that understanding is incomplete without accounting for white privilege denial.

We found ample evidence that white privilege denial matters. Examining the question of whether, and how, white privilege denial shaped support for candidates, presidents, and policy attitudes, in each of these dependent variables we found that white privilege denial mattered beyond measures of racial resentment, white identity, and white cconsciousness. White privilege denial gives shape to the party system by fostering support for Republican leaders (Donald Trump as candidate and president) and diminishing support for Democratic leaders (Hillary Clinton and Barack Obama). White privilege denial is also associated with a variety of racial and racialized policy attitudes. Those who deny white privilege are more likely to oppose affirmative action, social welfare spending, and liberal immigration policy. The denial of white privilege is also associated with opposition to NFL players "taking a knee" during the national anthem, and, to a lesser extent, belief in the birther conspiracy theory. The consistency of results for white privilege denial indicates that the political relevance of racial attitudes is not limited to negative evaluations of racial minorities but instead includes other, newer understandings of race, namely whether whites acknowledge their privileged, advantaged place in the racial hierarchy and how acknowledging this advantage diminishes favorable intergroup comparisons.

Racial resentment also played a prominent role in understanding the political views of white people. This 
was not unexpected. Any study of white racial attitudes in the United States requires an investigation of attitudes towards racial outgroups, especially Blacks. Not only is racial resentment the most prominent measure of white racial attitudes in the study of politics but its relevance has grown, having broadened during the Obama presidency (Tesler 2012, 2016) and deepened in the Trump era (Newman et al. 2021; Valentino, Neuner, and Vandenbroek 2018). Yet in looking at the effect sizes for racial resentment and white privilege denial, they were often of similar magnitude suggesting that white privilege denial captures something large and meaningful that racial resentment does not. Given the centrality of racial resentment to the study of politics, the consistently strong and comparable effects we found for white privilege denial is no small feat.

White identity and white consciousness also played an important role in our study. Yet these constructs were less consistently associated with sentiment towards politicians and policy preferences. This pattern of results was not surprising given that white identity and white consciousness are relevant to explaining policies that concern the interests of the racial ingroup, not racial outgroups (Jardina 2019). Given how these measures, especially white consciousness, are conceptually and empirically related to white privilege denial, exploring further how they are associated would be a fruitful line of inquiry.

In one such exploration, we used the white identity and white consciousness items to better understand whites who acknowledge the existence of white privilege. We believe that many of these whites are likely to lament the fact that it exists (lamenters), but some may embrace-or at least appreciate-their privilege (appreciators). Since our measure of white privilege denial cannot distinguish between appreciators and lamenters, we investigated it using white identity and white consciousness (online appendix K). Following Jardina (2019, 134), we had expected white identifiers (and those with white group consciousness) to be appreciators since it is "the feature of their group they desire to maintain and protect." Conversely, we had expected whites who were low in racial solidarity to be lamenters since they do not think of themselves in racial group terms. In brief, the results in online appendix $\mathrm{K}$ suggest that lamenters are more common than appreciators (although it depends on measurement), but regardless of whether we looked at lamenters or appreciators, privilege-acknowledging whites do not meaningfully differ in their political views. Both lamenters and appreciators are likely to self-identify as liberals, disapprove of President Trump, and hold liberal positions on racial policy. Since both groups hold similar political views, it suggests that some white liberals have moved beyond the invisibility of whiteness recognizing how being white is important to their own identity and politics (see Schildkraut 2019).
White privilege denial is about rejecting the notion that whiteness confers unearned advantages but for many whites denial may not go far enough. Most whites, for instance, believe that anti-white bias is more common than anti-Black bias (Norton and Sommers 2011). In her examination of white consciousness, Jardina (2019, 67) found a large majority of whites responded that it is at least "somewhat likely" that whites are discriminated against and that roughly one-fifth indicated that such discrimination is "very likely" or "extremely likely." The consequences of this belief have only recently materialized in electoral politics. Sides, Tesler, and Vavreck (2017) show that perceived discrimination against whites was unrelated to support for Republican candidates prior to 2016 but that it had a powerful effect on support for Trump in 2016, especially among whites mostly likely to believe their racial group faces discrimination. Future research should seek to understand the relationship between white privilege denial and perceptions of discrimination and how they inform political attitudes.

Another promising avenue for future research should examine the emotional foundations of white privilege denial. Previous work suggests that anger underpins racial resentment, whereas old-fashioned, biological racism is animated by disgust (Banks 2014; Banks and Valentino 2012). Activating these emotions may trigger different racial beliefs and increase opposition toward policies that increase racial equality such as affirmative action. White privilege, its acceptance or denial, may also very well have distinct emotional foundations. For those accepting white privilege, shame or guilt (see Chudy, Piston, and Shipper 2019) may be the associated emotion but for those who deny its existence, anger or indignation may be the emotional substrate.

In sum, although much work remains, our results have helped establish that whites' desire for group differentiation (by way of privilege denial) is strongly associated with political attitudes beyond racial resentment, racial group identity, or racial group solidarity. Nevertheless, the observational nature of our data precludes us from claiming a causal effect. Studies of racial attitudes suggest that they are relatively stable at the individual (Henry and Sears 2009; Kinder and Sanders 1996; Tesler and Sears 2010) and aggregate levels (Smith, Kreitzer, and Suo 2020), but politics can shape racial attitudes (Engelhardt 2021) and future research should make use of panel data or experiments to demonstrate a causal relationship.

Given the centrality of race for understanding the American political system, white privilege denial helps us better understand the racial landscape and how it shapes whites' thinking about politics. In asking whites whether they see themselves as benefactors of race in America, we are better able to understand the nature of their racial thoughts as well as how their racial understandings 
manifest themselves politically. In so doing, understanding white privilege denial further underscores the significance of race in explaining how white people think about the political world.

\section{Supplementary Materials}

To view supplementary material for this article, please visit http://dx.doi.org/10.1017/S1537592721004102.

Appendix A. White Privilege Items

Appendix B. Distribution of Racial Attitudes

Appendix C. Question Wording for WI, WC, SDO, Hostile Sexism, and Factor Analyses

Appendix D. Robustness Checks, Controlling for SDO and Sexism

Appendix E. Replication of Findings Using the Common Content in 2018 and 2020

Appendix F. Effects of the Racial Attitudes on ProRepublican Affective Polarization

Appendix G. Candidate Evaluations Analysis-Alternative

Appendix H. Interaction Effects of the Racial Attitudes by Ideology and Party ID

Appendix I. Presidential Approval Ordered Logit Analysis

Appendix J. Question Wording for Policy Items

Appendix K. Exploring the Acknowledgement of White Privilege using WI and WC

\section{Acknowledgement}

Earlier versions of this paper were presented at the Annual Meeting of the Western Political Science Association, San Diego, CA, April 18-20, 2019, and of the American Political Science Association, Boston, MA, August 31September 2, 2018. The authors would like to thank Tom Hansford, Kiku Huckle, Ashley Jardina, Cindy Kam, Jay Yeon Kim, Jenn Merolla, Alex Theodoridis, and Jessica Trounstine for helpful comments and suggestions.

\section{Notes}

1 The number of cases for any given analysis will necessarily be lower given missing data.

2 For the sake of maintaining comparability with racial resentment, we only use the group-level items from Swim and Miller (1999), excluding items about personal experiences.

\section{References}

Abrajano, Marisa, and Hajnal, Zoltan L. 2015. White Backlash: Immigration, Race, and American Politics. Princeton, NJ: Princeton University Press.

Abramowitz, Alan, and Jennifer McCoy. 2019. "United States: Racial Resentment, Negative Partisanship, and
Polarization in Trump's America." ANNALS of the American Academy of Political and Social Science 681(1): 137-56.

Ansolabehere, Stephen, and Douglas Rivers. 2013. "Cooperative Survey Research." Annual Review of Political Science 16(1): 307-3,29.

Banks, Antoine J. 2014. Anger and Racial Politics: The Emotional Foundation of Racial Attitudes in America. New York: Cambridge University Press.

Banks, Antoine J., and Nicholas A. Valentino. 2012. "Emotional Substrates of White Racial Attitudes."

American Journal of Political Science 56(2): 286-97.

Bonilla-Silva, Eduardo. 2006. Racism Without Racists: Color-Blind Racism and the Persistence of Racial Inequality in the United States. Lanham: Rowman \& Littlefield Publishers.

Bowler, Shaun, and Gary Segura. 2012. The Future Is Ours: Minority Politics, Political Behavior, and the Multiracial Era of American Politics. Thousand Oaks, CA: CQ Press/SAGE.

Brader, Ted, Nicholas A. Valentino, and Elizabeth Suhay. 2008. "What Triggers Public Opposition to Immigration? Anxiety, Group Cues, and Immigration Threat." American Journal of Political Science 52(4): 959-78.

Branscombe, Nyla R., Michael T. Schmitt, and Kristin Schiffhauer. 2007. "Racial Attitudes in Response to Thoughts of White Privilege." European Journal of Social Psychology 37(2): 203-15.

Brewer, Marilynn B. 1979. "In-Group Bias in the Minimal Intergroup Situation: A Cognitive Motivational Analysis." Psychological Bulletin 86(2): 307-24.

-. 1999. "The Psychology of Prejudice: Ingroup Love or Outgroup Hate?” Journal of Social Issues 55(3):429-44.

Carmines, Edward G., and James A. Stimson. 1989. Issue Evolution: Race and the Transformation of American Politics. Princeton, NJ: Princeton University Press.

Cassese, Erin C. and Mirya Holman. 2019. "Playing the Woman Card: Ambivalent Sexism in the 2016 US Presidential Race." Political Psychology 40(1):55-74.

Chudy, Jennifer, Spencer Piston, and Joshua Shipper. 2019. "Guilt by Association: White Collective Guilt in American Politics." Journal of Politics 81(3): 968-81.

Conway, John G., Nikolette P. Lipsey, Gabrielle Pogge, and Kate A. Ratliff. 2017. "Racial Prejudice Predicts Less Desire to Learn about White Privilege." Social Psychology 48(5): 310-19.

DeSante, Christopher D., and Candis Watts Smith. 2020a. Racial Stasis: The Millennial Generation and the Stagnation of Racial Attitudes in American Politics. Chicago: University of Chicago Press.

_. 2020b. "Fear, Institutionalized Racism, and Empathy: The Underlying Dimensions of Whites' 
Racial Attitudes." PS: Political Science \& Politics 53(4): 639-45.

Du Bois, W.E.B. 1935. Black Reconstruction in America: 1860-1880. New York: Harcourt, Brace.

Duran, Nicholas D., Stephen P. Nicholson, and Rick Dale. 2017. "The Hidden Appeal and Aversion to Political Conspiracies as Revealed in the Response Dynamics of Partisans." Journal of Experimental Social Psychology 73:268-78.

Engelhardt, Andrew M. 2021. "Racial Attitudes Through a Partisan Lens." British Journal of litical Science 51(3): 1062-79.

Golash-Boza, Tanya Maria. 2017. Race \& Racisms: A Critical Approach. New York: Oxford University Press.

Gilens, Martin. 1999. Why Americans Hate Welfare: Race, Media, and the Politics of Antipoverty Policy. Chicago: University of Chicago Press.

Hartmann, Douglas, Joseph Gerteis, and Paul R. Croll. 2009. "An Empirical Assessment of Whiteness Theory: Hidden from How Many?” Social Problems 56(3): 403-24.

Hainmueller, Jens, and Daniel J. Hopkins. 2014. "Public Attitudes toward Immigration." Annual Review of Political Science 17(1): 225-49.

Heit, Evan, and Stephen P. Nicholson. 2016. "Missing the Party: Political Categorization and Reasoning in the Absence of Party Label Cues." Topics in Cognitive Science 8(3): 697-714.

Henry, P.J., and David O. Sears. 2009. "The Crystallization of Contemporary Racial Prejudice across the Lifespan." Political Psychology 30(4): 569-90.

Hutchings, Vincent L., and Nicholas A. Valentino. 2004. "The Centrality of Race in American Politics." Annual Review of Political Science 7(1): 383-408.

Jardina, Ashley. 2019. White Identity Politics. Cambridge: Cambridge University Press.

Jardina, Ashley, and Spencer Piston. 2019. "Racial Prejudice, Racial Identity, and Attitudes in Political Decision Making." In Oxford Research Encyclopedia of Politics. New York: Oxford University Press.

Jardina, Ashley, and Michael Traugott. 2019. "The Genesis of the Birther Rumor: Partisanship, Racial Attitudes, and Political Knowledge. Journal of Race, Ethnicity, and Politics (4): 60-80.

Jefferson, Hakeem, and Kohi Takahshi. 2021. "How the Politics of White Liberals and White Conservatives Are Shaped by Whiteness." FiveThirtyEight, May 10 (https://fivethirtyeight.com/features/how-thepolitics-of-white-liberals-and-whiteconservatives-areshaped-by-whiteness/).

Kinder, Donald R. 2013. "Prejudice and Politics." In The Oxford Handbook of Political Psychology, ed. Leonie
Huddy, David O. Sears, and Jack Levy. New York: Oxford University Press.

Kinder, Donald R., and Cindy D. Kam. 2009. Us against Them: Ethnocentric Foundations of American Opinion. Chicago: University of Chicago Press.

Kinder, Donald R., and Lynn M. Sanders. 1996. Divided by Color: Racial Politics and Democratic Ideals. Chicago: University of Chicago Press.

Kinder, Donald R., and David O. Sears. 1981. "Prejudice and Politics: Symbolic Racism versus Racial Threats to the Good Life." Journal of Personality and Social Psychology 40(3): 414-31.

Knowles, Eric D., Brian S. Lowery, Rosalind M. Chow, and Miguel M. Unzueta. 2014. "Deny, Distance, or Dismantle? How White Americans Manage a Privileged Identity." Perspectives on Psychological Science 9(6): 594-609.

McIntosh, Peggy. 1988. "White Privilege: Unpacking the Invisible Knapsack." Peace and Freedom, July/August. $10-12$.

Mendelberg, Tali. 2001. The Race Card: Campaign Strategy, Implicit Messages, and the Norm of Equality. Princeton, NJ: Princeton University Press.

Miller, Joanne M., Kyle L. Saunders, Christina E. Farhart. 2016. "Conspiracy Endorsement as Motivated Reasoning: The Moderating Roles of Political Knowledge and Trust." American Journal of Political Science 60(4): 824-44.

Myrdal, Gunnar. 1944. An American Dilemma: The Negro Problem and Modern Democracy. New York: Harper and Brothers.

Newman,Ben, Jennifer Merolla, Sono Shah, Danielle Casarez Lemi, Loren Collingwood, and Karthick Ramakrishnan. 2021. "The Trump Effect: An Experimental Investigation of the Emboldening Effect of Racially Inflammatory Elite Communication." British Journal of Political Science 51(3): 1138-59.

Nicholson, Stephen P. 2005. Voting the Agenda: Candidates, Elections, and Ballot Propositions. Princeton, NJ: Princeton University Press.

Norton, Michael I., and Samuel R. Sommers. 2011. "Whites See Racism as a Zero-Sum Game That They Are Now Losing." Perspectives on Psychological Science 6 (3): 215-18.

Pager, Devah, and Hana Shepherd. 2008. "The Sociology of Discrimination: Racial Discrimination in Employment, Housing, Credit, and Consumer Markets." Annual Review of Sociology 34(1): 181-209

Parker, Christopher S., and Matt A. Barreto. 2013. Change They Can't Believe In: The Tea Party and Reactionary Politics in America. Princeton, NJ: Princeton University Press. 
Pérez, Efrén O. 2010. "Explicit Evidence on the Import of Implicit Attitudes: The IAT and Immigration Policy Judgments." Political Behavior 32(4): 517-45.

- 2016. Unspoken Politics: Implicit Attitudes and Political Thinking. New York: Cambridge University Press.

Phillips, L. Taylor, and Brian S. Lowery. 2015. "The Hard-Knock Life? Whites Claim Hardships in Response to Racial Inequity." Journal of Experimental Social Psychology 61:12-18.

- 2018. "Herd Invisibility: The Psychology of Racial Privilege." Current Directions in Psychological Science 27 (3): 156-62.

Philpot, Tasha. 2007. Race, Republicans, and the Return of the Party of Lincoln. Ann Arbor: University of Michigan Press.

Pratto, Felicia, Jim Sidanius, Lisa M. Stallworth, and Bertram F. Malle. 1994. "Social Dominance Orientation: A Personality Variable Predicting Social and Political Attitudes." Journal of Personality and Social Psychology 67(4): 741-63.

Rabinowitz, Joshua L., David O. Sears, Jim Sidanius, and Jon A. Krosnick. 2009. "Why Do White Americans Oppose Race-Targeted Policies? Clarifying the Impact of Symbolic Racism." Political Psychology 30(5): 805-28.

Reny, Tyler T., Loren Collingwood, and Ali A. Valenzuela. 2019. "Vote Switching in the 2016 Election: How Racial and Immigration Attitudes, Not Economics, Explain Shifts in White Voting." Public Opinion Quarterly 83(1): 91-113.

Rothstein, Richard. 2017. The Color of Law: A Forgotten History of How Our Government Segregated America. New York: W.W. Norton

Rovell, Darren. 2016. "Poll: Niners QB Colin Kaepernick Most Disliked Player in League." ESPN, September 21 (https://www.espn.com/nfl/story/_/id/17604958/ san-francisco-49ers-qb-colin-kaepernick-mostdisliked-player-nfl-according-poll-e-poll-marketingresearch).

Schaffner, Brian F. 2021. "Optimizing the Measurement of Sexism in Political Surveys." Political Analysis, 1-17. doi:10.1017/pan.2021.6

Schildkraut, Deborah J. 2010. Americanism in the TwentyFirst Century: Public Opinion in the Age of Immigration. New York: Cambridge University Press.

- 2019. "The Political Meaning of Whiteness for Liberals and Conservatives." The Forum 17(3): 421-46.

Schuman, Howard, Charlotte Steeh, Lawrence Bobo, and Maria Krysan. 1997. Racial Attitudes in America: Trends and Interpretations. Cambridge, MA: Harvard University Press.
Sears, David O., and P.J. Henry. 2003. "The Origins of Symbolic Racism." Journal of Personality and Social Psychology 85(2): 259-75.

Segura, Gary M., and Ali A. Valenzuela. 2010. "Hope, Tropes, and Dopes: Hispanic and White Racial Animus in the 2008 Election." Presidential Studies Quarterly 40 (3): 497-514.

Sheagley, Geoffrey, Philip Chen, and Christina Farhart. 2017. "Racial Resentment, Hurricane Sandy, and the Spillover of Racial Attitudes into Evaluations of Government Organizations." Analyses of Social Issues and Public Policy 17(1): 105-31.

Sides, John M., M. Tesler, and Lynn Vavreck. 2017. "Donald Trump and the Rise of White Identity Politics." Presented at "The 2016 U.S. Presidential Election: Tumult at Home, Retreat Abroad?" conference at the Mershon Center, Ohio State University, November 3-4.

Sides, John, Michael Tesler, and Lynn Vavreck. 2019. Identity Crisis: The 2016 Presidential Campaign and the Battle for the Meaning of America. Princeton, NJ: Princeton Press.

Smith, Candis Watts, Rebecca J. Kreitzer, and Feiya Suo. 2020. "The Dynamics of Racial Resentment across the 50 US States." Perspectives on Politics 18(2): 527-38.

Sniderman, Paul M., and Philip E. Tetlock. 1986.

"Symbolic Racism: Problems of Motive Attribution in Political Analysis." Journal of Social Issues 42(2): 129-50.

Swim, Janet K., and Deborah L. Miller. 1999. "White Guilt: Its Antecedents and Consequences for Attitudes toward Affirmative Action." Personality and Social Psychology Bulletin 25(4): 500-14.

Tajfel, Henri. 1974. "Social Identity and Intergroup Behaviour.” Social Science Information 13(2): 65-93.

Tajfel, Henr, and John Turner. 1979. "An Integrative Theory of Intergroup Conflict.” In The Social Psychology of Intergroup Relations, ed. William G. Austin and Stephen Worchel, 33-47. Monterey: Brooks/Cole.

Tarman, Christopher, and David O. Sears. 2005. "The Conceptualization and Measurement of Symbolic Racism." Journal of Politics 67(3): 731-61.

Tesler, Michael. 2012. "The Spillover of Racialization into Health Care: How President Obama Polarized Public Opinion by Racial Attitudes and Race." American Journal of Political Science 56 (3): 690-704. —. 2015. "The Conditions Ripe for Racial Spillover Effects." Advances in Political Psychology 36: 101-117. - 2016. Post-Racial or Most-Racial? Race and Politics in the Obama Era. Chicago: University of Chicago Press. Tesler, Michael, and David O. Sears. 2010. Obama's Race: The 2008 Election and the Dream of A Post-Racial America. Chicago: University of Chicago Press. 
Trounstine, Jessica. 2016. Segregation by Design: Local Politics and Inequality in American Cities. New York: Cambridge University Press.

Valentino, Nicholas A., Ted Brader, and Ashley E. Jardina. 2013. "Immigration Opposition among US Whites: General Ethnocentrism or Media Priming of Attitudes about Latinos?” Political Psychology 34(2): 149-66.
Valentino, Nicholas A., Vincent L. Hutchings, and Ismail K. White. 2002. "Cues That Matter: How Political Ads Prime Racial Attitudes during Campaigns." American Political Science Review 96(1): 75-90.

Valentino, Nicholas A., Fabian G. Neuner, and L. Matthew Vandenbroek. 2018. "The Changing Norms of Racial Political Rhetoric and the End of Racial Priming." Journal of Politics 80(3): 757-71. 